\title{
Gender, Risk-Taking Propensity and Culture of Entrepreneurs at Small and Medium Enterprises in Gauteng
}

\author{
Ajay K Garg11, Peter Letsolo \\ TUT Business School, Pretoria, South Africa \\ PO BOX 602, Buccleuch, Bramley, 2066 \\ Gargak@tut.ac.za
}

\begin{abstract}
This study analyzed the risk-taking propensity amongst the four cultural groups and its impact on the business performance, from a sample of Small and Medium Enterprises (SMEs) within the Gauteng Province of South Africa. The data was collected using two sets of questionnaire measuring risk taking propensity and perceived business performance. 83 responses were returned from 400 respondents. The results indicate that male on average show higher risk taking, while difference in risk taking propensity between male and female was not statistically significant. A very weak or no correlation between risk taking and business performance scores for both the genders were found, indicating that gender and culture does not play a role in the relationship between risk taking and business performance. However study found that there was significant difference in risk taking behavior by different culture groups, Zimbabweans were the highest risk takers, while Chinese, Pakistanis and South Africans differed in their risk taking behavior.
\end{abstract}

Keywords: Entrepreneurship, risk, Culture, business performance, South Africa

\section{Introduction}

After 22 years of black rule, South Africa is still at transition stage in terms of distribution of wealth. Although the political power is transferred in the hands of black people, the business still is dominated by white natives. The black economic empowerment policy of the South African Government has resulted in transferring some businesses to a minority few but redistribution of wealth still remains a challenge. The internal labor problems, recession of 2008 and current slowdown in China has affected South African economy adversely. As an added mechanism to citizen empowerment, South African government has embarked on enhancing entrepreneurship to create jobs and redistribute wealth. To this end several schemes have been launched by the Government to enhance entrepreneurial activities. However as per GEM report (2015), entrepreneurial activity in South Africa, although very low, has increased marginally over the last 10 years, but in 2014 dropped by a staggering 34\% (from $10.6 \%$ to $7 \%$ ). Low level of labor efficiency, high level of crime and corruption are some of the factors that have hindered entrepreneurs to flourish in South Africa. However South African borders are open to immigrants and there are good number of small businesses operated by Chinese, Pakistanis, Zimbabweans, other African nationals (Ethiopians, Congolese, Kenyans etc.), while majority of Indians and Pakistanis from apartheid regime own big businesses in South Africa. Given this background, the objective of this study was to analyze the risk-taking propensity amongst the various cultural groups and its impact on the business performance, from a sample of Small and Medium Enterprises (SMEs) within the Gauteng Province of South Africa, which is the seat of highest entrepreneurial activities in South Africa.

\section{Literature Review}

Literature on entrepreneurship considers two types of cultures; organizational culture and national culture. Organizational culture relates to the individual behaviour and interaction of individuals with organization. Despande and Webster (1989), Quinn (1988), Cameron and Quinn (1999) are the pioneers in developing organizational culture while researchers like Kangas (2009); Valencia, Valle and Jimenez (2010) have studied

\footnotetext{
${ }^{1}$ Corresponding author, The agreed contribution ratio between first and second author is 80:20
} 
various types of organizational culture in the domain of entrepreneurship. The essential core of national culture consists of traditional ideas and especially their attached values (Kluckhohn, 1951). National culture has been studied in entrepreneurial context by several authors, however the cultural dimensions proposed by Hofsfede (2001) are the most accepted by researchers. Webster and White (2010) made a call to address the role of national culture on the relationship between organizational culture and entrepreneurship. Several authors (McGrath et al., 1992; Busenitz, Gómez and Spencer, 2000; Lee and Peterson, 2000; Mueller and Thomas, 2000; Stephan and Uhlaner, 2010; Autio, Pathak and Wennberg, 2013, Engelen et al., 2014) have studied relationship between organizational culture and entrepreneurship, but the relationship remains inconclusive.

Risk taking has been associated with entrepreneurship. There is no dearth of literature risk taking and entrepreneurship. However there are recent studies (for example Kreiser et al., 2010; Mihet, 2013) that have studied the impact of national culture on risk taking. These studies find a good interplay between organizational culture, national culture and risk taking. Gender and ethnic culture further plays a role in entrepreneurship. Based on Meta analysis of 150 studies, Byrnes et al. (1999) found that risk taking was significantly larger among males as compared to females. Garg and Duvenhage (2014) also found that female were risk averse as compared to male counterpart. There are several studies exploring this relationship, Zeffane (2015) further explored the reasons for such disparities and found that females were less trusting than males, and the intention to engage in entrepreneurship is most significantly affected by propensity to trust. Mungai and Ogot (2012) found that ethnic culture influence play a larger role in women's propensity towards entrepreneurship and is pronounced even when men and women from the same community are compared along the same dimension.

Motivation for current study: There has been extensive literature studying the effects of organizational culture, national culture, risk taking and gender on entrepreneurship. These factors are classified as environmental (social, cultural and political) factors that play a role in the entrepreneurship (Torro et al., 2014). Most of the studies (for example Kreiser et al., 2010; Mihet, 2013; Engelen et al., 2014) dealing with the role of culture focus various countries to differentiate the cultural values, however, the drawback of such studies are that the business environment varies in countries and effect of culture is likely to be effected by variations in environmental conditions. Hence in this study, entrepreneurial behavior was considered in a single economy whereby different cultural were considered for their risk taking capabilities linked to business performance. Accordingly objectives of this study were to measure the risk propensity of entrepreneurs from the four chosen cultural groups, namely Chinese, Zimbabwean, Pakistani and South African, and to study the relationship between risk taking inclination per cultural group, business performance and gender. South African environment was considered to provide contribution to the theory from such perspective.

\section{Research design}

A survey was designed. The questionnaires used in this study have been designed based on previous research studies. As a first questionnaire, The Domain-Specific Risk-Taking (DOSPERT) Scale was selected as it assesses perceived-risk attitudes in five frequently encountered content areas, namely ethical, financial, health/safety, social, and recreational decisions (Weber et al., 2002). The questionnaire has been used and validated, and its factor structure replicated in a wide range of settings and populations. The goal of this study was to use the DOSPERT scale to measure entrepreneurs' attitudes toward risk activities. A second questionnaire, to measure business performance, that was developed by the first author (Garg et al., 2004)

was used. The validity and reliability of these two questionnaires have been tested and verified in number of settings. The targeted population was small- to medium- sized businesses owned by entrepreneurs in the Gauteng Province of South African. The population was chosen from four cultural groups, namely Zimbabwean, Chinese, Pakistani and local South African. Participants in this study were selected based on three criteria: the entrepreneur must be the owner of the business or have at least a $50 \%$ share in the business; the entrepreneur's business must have been in operation for at least 12 months and participants can only belong to the four cultural groups, Zimbabwean, Chinese, Pakistani and local South African. Based on Department of Trade and Industry, the total population of SME in Gauteng is estimated at 77 850, there are no 
estimates per cultural group available. A sample of 100 randomly selected respondents per cultural group was approached.

\section{Data Analysis and Results}

A total of 83 out of 400 questionnaires was successfully completed and returned, resulting in a response rate of $21 \%$. There were 40 male and 43 females respondents across the four cultural groups. Amongst the male respondents $3.61 \%$ were Chinese, $10.84 \%$ were Pakistani, $25.30 \%$ were South African and $8.43 \%$ were Zimbabwean. While amongst female respondents $6.02 \%$ were Chinese, $15.66 \%$ were Pakistani, $20.48 \%$ were South African and $9.64 \%$ were Zimbabwean. A large percentage (37\%) of respondents had their businesses running for 4 to 6 years. South Africans had a higher percentage of shareholding, while Zimbabweans were second and Pakistanis were third, Chinese were last on both ownership and shareholding.

Risk taking propensity and business performance perceptions amongst males and females

Table 1 shows the overall risk taking propensity between male and female. It also shows the business performance scores and risk taking propensity in different domains.

Table 1: Mean rate of risk perception and business performance for male and female respondents

\begin{tabular}{llllllll}
\hline $\begin{array}{l}\text { Respondents } \\
\text { (n=83) }\end{array}$ & $\begin{array}{l}\text { Overall } \\
\text { Risk } \\
\text { Perception }\end{array}$ & $\begin{array}{l}\text { Ethical } \\
\text { Risk } \\
\text { Perception }\end{array}$ & $\begin{array}{l}\text { Health and } \\
\text { Safety Risk } \\
\text { Perception }\end{array}$ & $\begin{array}{l}\text { Financial } \\
\text { Risk } \\
\text { Perception }\end{array}$ & $\begin{array}{l}\text { Recreational } \\
\text { Risk } \\
\text { Perception }\end{array}$ & $\begin{array}{l}\text { Social Risk } \\
\text { Perception }\end{array}$ & $\begin{array}{l}\text { Business } \\
\text { Performance }\end{array}$ \\
\hline Male & 2.81 & 2.77 & 2.79 & 2.79 & 2.75 & 2.95 & 3.10 \\
Female & 2.68 & 2.62 & 2.63 & 2.85 & 2.62 & 2.65 & 3.50 \\
p values & 0.151 & 0.192 & 0.173 & 0.339 & 0.229 & $0.05^{*}$ & - \\
\hline
\end{tabular}

*significant at 5\%

Table 1 indicates that males on average show higher risk taking profiles. While it highlights that men are perceived to take more risk in most of the domains, female scored higher in financial risk domain. The study further indicates that female respondents have a higher business performance mean score indicating that they believe their businesses' performance to be better than their competitors', while male respondents mean score to be only 3.10. The relationship between male and female entrepreneurs' risk taking perception was analyzed using the difference in mean average of each risk-taking domain. The p-value indicates the probability of this relationship's significance. Since the p values lies above $5 \%$ for most of the instances, it can be inferred with confidence that there is no difference in the mean scores for males and females in overall risk taking perception in all domains studied except the social domain.

Relationship between risk taking and business performance for male/female entrepreneurs

Table 2 shows the relationship between risk taking and business performance per gender.

Table 2: Risk Taking and Business Performance

\begin{tabular}{|c|c|c|c|c|c|c|c|c|}
\hline \multirow[t]{2}{*}{ Risk Domain } & \multirow{2}{*}{$\begin{array}{l}\begin{array}{l}\text { Risk } \\
(\mathrm{x})\end{array} \\
\text { Male }\end{array}$} & \multirow{2}{*}{$\begin{array}{l}\text { Domain } \\
\text { Female }\end{array}$} & \multicolumn{2}{|c|}{$\begin{array}{l}\text { Business } \\
\text { Performance } \\
\text { (v) }\end{array}$} & \multicolumn{2}{|c|}{$\begin{array}{l}\text { Correlation } \\
\text { Coefficient(r) }\end{array}$} & \multicolumn{2}{|c|}{$\begin{array}{l}\text { Correlation of } \\
\text { determination }\left(r^{2}\right)\end{array}$} \\
\hline & & & Male & Female & Male & Female & Male & Female \\
\hline $\begin{array}{ll}\text { Overall } & \text { Risk } \\
\text { Perception } & \end{array}$ & 2.81 & 2.68 & 3.10 & 3.50 & 0.0084 & -0.037 & $0.007 \%$ & $0.137 \%$ \\
\hline Ethical domain & 2.77 & 2.62 & 3.10 & 3.50 & -0.0143 & 0.0175 & $0.025 \%$ & $0.03 \%$ \\
\hline $\begin{array}{l}\text { Health and Safety } \\
\text { domain }\end{array}$ & 2.78 & 2.63 & 3.10 & 3.50 & 0.0910 & -0.056 & $0.83 \%$ & $0.31 \%$ \\
\hline Finance domain & 2.79 & 2.85 & 3.10 & 3.50 & -0.126 & -0.098 & $1.58 \%$ & $0.96 \%$ \\
\hline $\begin{array}{l}\text { Recreational } \\
\text { domain }\end{array}$ & 2.75 & 2.62 & 3.10 & 3.50 & -0.176 & -0.915 & $3.09 \%$ & $83.7 \%$ \\
\hline Social domain & 2.95 & 2.65 & 3.10 & 3.50 & 0.0295 & 0.0515 & $0.087 \%$ & $0.26 \%$ \\
\hline
\end{tabular}


The table 2 shows the correlation coefficient ( $r$ ) and the correlation of determination $\left(r^{2}\right)$ between risk taking perceptions and business performance. The various $r$ values show very weak or no correlation between the risk taking and business performance for both male and female category. This study found no relationship between risk and business performance for both male and female respondents.

Culture in risk perceptions and business performance.

Culture and risk taking propensity: Table 3 shows the risk taking propensity scores and business performance scores per culture. The average score shows that Zimbabweans were the highest risk takers in overall and in most of the domains, followed by South Africans. However the scores from other cultures were also very close. In order to find whether the risk scores differ between cultures, t test ( $p$ values) was performed and table 4 reports the $p$ values between different culture's scores.

Table 3: Risk taking propensity per culture

\begin{tabular}{llllllll}
\hline Respondents & $\begin{array}{l}\text { Overall } \\
\text { Risk } \\
\text { Perception }\end{array}$ & $\begin{array}{l}\text { Ethical } \\
\text { Risk } \\
\text { Perception }\end{array}$ & $\begin{array}{l}\text { Health and } \\
\text { Safety Risk } \\
\text { Perception }\end{array}$ & $\begin{array}{l}\text { Financial } \\
\text { Risk } \\
\text { Perception }\end{array}$ & $\begin{array}{l}\text { Recreational } \\
\text { Risk } \\
\text { Perception }\end{array}$ & $\begin{array}{l}\text { Social Risk } \\
\text { Perception }\end{array}$ & $\begin{array}{l}\text { Business } \\
\text { Performance }\end{array}$ \\
\hline Chinese & 2.50 & 2.33 & 2.27 & 2.90 & 2.27 & 2.70 & 3.60 \\
Pakistani & 2.74 & 2.75 & 2.69 & 2.70 & 2.68 & 2.86 & 3.96 \\
South African & 2.75 & 2.66 & 2.71 & 2.84 & 2.82 & 2.70 & 2.78 \\
Zimbabwean & 2.86 & 2.87 & 2.97 & 2.90 & 2.54 & 3.01 & 3.53 \\
\hline
\end{tabular}

Table 4: $p$ values showing the difference in Risk taking scores between the two cultures

\begin{tabular}{lllll}
\hline Risk Domain & Culture & Pakistani & South African & Zimbabwean \\
\hline Overall & Chinese & $0.0749^{* *}$ & $0.0979^{* *}$ & 0.1114 \\
& Pakistani & & 0.48783 & 0.2653 \\
\multirow{2}{*}{ Ethical } & South African & & & 0.2934 \\
& Chinese & $0.0935^{* *}$ & 0.1435 & $0.06398^{* *}$ \\
& Pakistani & & 0.3233 & 0.3262 \\
Health and & South African & & & 0.2034 \\
Safety & Chinese & $0.1074^{* *}$ & $0.1067^{* *}$ & $0.0429^{*}$ \\
\multirow{3}{*}{ Financial } & Pakistani & & 0.45640 & 0.13580 \\
& South African & & & 0.16743 \\
\multirow{5}{*}{ Recreational } & Chinese & 0.27874 & 0.43645 & 0.49544 \\
& Pakistani & & 0.19166 & 0.18450 \\
\multirow{5}{*}{ Social } & South African & & & 0.40286 \\
& Chinese & $0.03444^{*}$ & $0.00963^{*}$ & 0.20001 \\
& Pakistani & & 0.23300 & 0.32626 \\
& South African & & & 0.18843 \\
& Chinese & 0.24863 & 0.49560 & 0.14742 \\
& Pakistani & & 0.16637 & 0.25974 \\
\hline
\end{tabular}

${ }^{*}$ statistically significant at $5 \%{ }^{* *}$ statistically significant at $10 \%$

The $\mathrm{p}$ values show that there were differences in overall risk taking between Chinese, Pakistanis and South Africans, however Zimbabweans did not show any statistical difference in risk taking with other cultures. Zimbabweans showed differences in risk taking with Chinese in Ethical and Health \& safety risk domain and with South African in social risk domains. Chinese showed differences with Pakistanis in Ethical, health \&safety and recreational domains. South African showed differences in health \& safety and recreational risk domains with Chinese. Zimbabweans showed highest risk taking propensity amongst cultures but did not show any statistical difference with other cultures in risk taking propensity. The results suggest differences in different types of risk taking propensity among different cultural domains.

Culture and business performance: Table 5 shows scores for risk domain and business performance scores per culture group. Table 6 shows the coefficient of correlation between risk and business performance. 
Table 5: Cultural Group on Risk Taking and Business Performance scores

\begin{tabular}{lllllllll}
\hline Risk Domain & \multicolumn{2}{l}{ Cultural domain } & \multicolumn{5}{c}{ Business Performance } \\
& Chinese & Pakistani & $\begin{array}{l}\text { South } \\
\text { African }\end{array}$ & Zimbabwean & Chinese & Pakistani & $\begin{array}{l}\text { South } \\
\text { African }\end{array}$ & Zimbabwean \\
\hline Overall & 2.50 & 2.74 & 2.75 & 2.86 & 3.60 & 3.96 & 2.78 & 3.53 \\
Ethical & 2.53 & 2.75 & 2.66 & 2.87 & 3.60 & 3.96 & 2.78 & 3.53 \\
Health \& Safety & 2.27 & 2.69 & 2.71 & 2.97 & 3.60 & 3.96 & 2.78 & 3.53 \\
Finance & 2.90 & 2.70 & 2.84 & 2.90 & 3.60 & 3.96 & 2.78 & 3.53 \\
Recreational & 2.27 & 2.68 & 2.82 & 2.54 & 3.60 & 3.96 & 2.78 & 3.53 \\
Social & 2.70 & 2.86 & 2.70 & 3.01 & 3.60 & 3.96 & 2.78 & 3.53 \\
\hline
\end{tabular}

Table6: Coefficient of correlation between risk and business performance scores per culture groups

\begin{tabular}{|c|c|c|c|c|c|c|c|c|}
\hline \multirow[t]{2}{*}{ Risk Domain } & \multicolumn{4}{|c|}{ Correlation Coefficient (r) } & \multicolumn{4}{|c|}{ Correlation of determination $\left(r^{2}\right)$} \\
\hline & Chinese & Pakistani & $\begin{array}{l}\text { South } \\
\text { African } \\
\end{array}$ & Zimbabwean & Chinese & Pakistani & $\begin{array}{l}\text { South } \\
\text { African }\end{array}$ & Zimbabwean \\
\hline Overall & -0.110 & 0.120 & 0.0401 & -0.320 & $1.2 \%$ & $1.4 \%$ & $0.160 \%$ & $10.24 \%$ \\
\hline Ethical & -0.022 & 0.390 & -0.040 & -0.430 & $0.048 \%$ & $15.2 \%$ & $0.16 \%$ & $18.9 \%$ \\
\hline Health \& Safety & 0.592 & -0.179 & -0.053 & -0.084 & $34.9 \%$ & $3.2 \%$ & $0.280 \%$ & $0.705 \%$ \\
\hline Finance & -0.130 & 0.0016 & -0.191 & -0.280 & $1.69 \%$ & $0.00026 \%$ & $3.64 \%$ & $7.84 \%$ \\
\hline Recreational & -0.097 & -0.022 & 0.043 & -0.435 & $0.94 \%$ & $0.046 \%$ & $0.184 \%$ & $18.9 \%$ \\
\hline Social & 0.139 & 0.0034 & 0.093 & 0.0563 & $1.932 \%$ & $0.00116 \%$ & $8.64 \%$ & $3.18 \%$ \\
\hline
\end{tabular}

While the business performance scores (Table 5) varied between culture groups, the coefficient of correlation between these parameters suggest very weak positive (South African and Pakistanis) to negative (Chinese and Zimbabweans) correlation between risk taking and business performance. The correlation of determinant is less than $50 \%$ for all the cases, these correlations are not significant. Hence it can be concluded that culture did not play a significant role in risk taking and business performance relationship.

\section{Discussion and Conclusion}

This study found that males on average show higher risk taking profiles compared to women in general. However there was no difference in the mean scores for males and females in overall risk taking perception in all the risk domains except the social risk domain. Further there was no statistically valid relationship between risk taking behavior and perceived business performance by both male and female. These findings suggest that there are commonalities and differences in men and women entrepreneurs. This is aligned with the findings by Garg \& Duvenhage (2014), Zeffan (2015), which indicated higher risk taking profiles by men entrepreneurs. There is an agreement in the literature that certain factors influence males and females differently, for example Bride et al., (2003) found that women are not being taken seriously by providers of funds when applying for funds and Katepa-Kalala (1999) acknowledged that women have access to fewer resources than men. More studies are required in South African context to establish which factors affect men and women entrepreneurs risk taking capabilities differently.

As indicated earlier, environmental factors such as social, cultural and political factors do play a role in the entrepreneurship, this study focused on studying the impact of culture in risk taking by entrepreneurs. The study found that there were significant differences in risk taking behavior by different culture groups. Zimbabweans were the highest risk takers, while Chinese, Pakistanis and South Africans differed in their risk taking behaviors. These findings contribute to the study by Kreiser et al. (2010), who found that various dimensions of cultural values representative of national culture impact the willingness of entrepreneurial firms to display risk taking and proactive behavior. This study also supports Mihet (2013) who found that risk taking by foreign firms is best explained by the cultural norm of the country of origin. However earlier studies for example Schubert, Brown, Gysler \& Brachinger, (1999) found that cultural groups do not generally make less risky financial choices than others. There was no valid correlation found between risk taking propensity and perceived business performance per culture group. This study also found very weak to no correlation between risk taking propensity and business performance scores for male and female respondents. This suggest that gender and culture does not play a role in the relationship between risk taking 
and business performance, however risk taking propensity varies with gender and cultural factors does impact risk taking propensity.

Contribution to the Theory and Implications of the Study: There has been some tend in recent studies that have found cultural aspect in entrepreneurial behavior. Understanding the risk taking propensity of cultural groups, could give a better understanding of why some cultural groups become entrepreneurial than others. However as indicated earlier there is no study that has studied the cultural difference, risk taking capabilities and other entrepreneurial variables in a single environment. Hence the finding of this study for such entrepreneurial behavior eliminates the effects that may arise due to differing opportunities posed by different economies, a key variable that distorts entrepreneurial behavior. The findings of this study can also make contribution in entrepreneurial policy formulation on specific gender and related issues in entrepreneurship, by South African government.

Acknowledgements: We express our gratitude to the referees' comments which has helped us to improve quality of this paper. We express our thanks to Mrs. Eunice Mtshali and her team in providing all library support. The views expressed in this paper are our own.

\section{References}

Autio, E., S. Pathak, \& Wennberg, K. (2013). Consequences of Cultural Practices for Entrepreneurial Behaviors. Journal of International Business Studies, 44(2), 334-362.

Busenitz, L., Gomez, W. J. \& Spencer, J. (2000). Country Institutional Profiles: Unlocking Entrepreneurial Phenomena. Academy of Management Journal, 43(5), 994-1003.

Byrnes, J. P., Miller, D. C. \& Schafer, W. D. (1999). Gender differences in risk-taking: a Meta analysis. Psychological Bulletin, 125(3), 367-383

Cameron, K. S. \& Quinn, R. E. (1999). Diagnosing and changing organizational culture: Based on the competing values framework. Reading, MA: Addison-Wesley

Quinn, J. (1988). Beyond Rational Management John Wiley and Sons.

Despande, R. \& Webster, F. (1989). Organizational Culture and Marketing: Defining the Research Agenda. Journal of Marketing, 53(1), 3-15

Engelen, A., Flatten, T. C., Thalmann, J. \& Brettel, M. (2014). The effect of Organizational Culture on Entrepreneurial Orientation: A Comparison between Germany and Thailand. Journal of Small Business Management, 52(4), 732-752.

Garg, A. K. \& Duvenhage, A. (2014). Risk taking patterns of male and female entrepreneurs in Roodeppoort: A case study. African and Asian Studies, 13(4), 452-478

Garg, A. K., Joubert, R. J. O. \& Pellisier, R. (2004). Measuring business performance: A case study. Southern African Business Review, 8(1), 7-21

GEM Report. (2014). An alarmingly low level of entrepreneurial activity in spite of high unemployment; available from http://www.gemconsortium.org/country-profile/108

Kangas, L. (2009). Assessing the Value of the Relationship between Organizational Culture Types and Knowledge Management Initiatives. Journal of Leadership Studies, 3(1), 29-38

Katepa-Kalala, P. (1999). Assessment report on women and poverty and economic empowerment of woman. http://www.uncca.org.

Kluckhohn, C. (1951). The Study of Culture. In The Policy Standard. Eds. D. Lerner and H. Lasswell. Cambridge: Harvard University Press: 393-404.

Kreiser, P. M., Marino, L. D., Dickson, P. \& Weaver, K. (2010). Cultural Influences on Entrepreneurial Orientation: The Impact of National Culture on Risk Taking and Proactiveness in SMEs. Entrepreneurship Theory and Practice, 34(5), 959-983.

Lee, S. M. \& Peterson, S. J. (2000). Culture, Entrepreneurial Orientation, and Global Competitiveness. Journal of World Business, 35(4), 401-416

Mcgrath, R. G., Macmillan, I. C., Yang, E. A. \& Tsai, W. (1992). Does Culture Endure, or is it Malleable? Issues for Entrepreneurial Economic Development. J Bus Venturing, (7), 115-135

Mihet, R. (2013). Effects of culture on firm risk-taking: a cross-country and cross-industry analysis. J Cult Econ., 37, 109-151. 
Mueller, S. L. \& Thomas, A. S. (2000). Culture and Entrepreneurial Potential: A Nine Country Study of Locus of Control and Innovativeness. Journal of Business Venturing, 16, 51-75.

Mungai, E. N. \& Ogot, M. (2012). Gender, Culture and Entrepreneurship in Kenya. International Business Research, 5(5), 175-183.

Stephan, U. \& Uhlander, L. M. (2010). Performance-Based vs Socially Supportive Culture: A Cross-National Study of Descriptive Norms and Entrepreneurship. Journal of International Business Studies, 41(8), 1347-1364.

Schubert, R., Brown, M., Gysler, M. \& Brachinger, H. (1999). Financial decision making: are women really more risk averse. American Economic Review, 89, 381.

Torro, A., Urbano, D. \& Peris-Oritz, M. (2014). Culture and innovation: The moderating effect of cultural values on corporate entrepreneurship. Technological Forecasting \& Social Change, 88, 360-369.

Valencia, J., Valley, R. \& Jimenz, D. (2010). Organizational Culture as Determinants Product Innovation. European Management Journal, 13(4), 466-480.

Webster, C. \& White, A. (2010). Exploring the National and Organizational Culture Mix in Service Firms. Journal of Academy of Marketing Sciences, 38(6), 691-703.

Weber, E. U., Blais, A. R. \& Betz, E. (2002). A Domain-specific risk-attitude scale: Measuring risk perceptions and risk behaviours. Journal of Behavioural Decision Making, 15, 263-290.

Zeffane, R. (2015). Trust, personality, risk taking and entrepreneurship. World Journal of Entrepreneurship, Management and Sustainable Development, 11(3), 191-209. 